\title{
Achilles alkancellár Halicsban 1246-ban
}

\section{Adalék a magyar vice szó történetéhez}

1.Vice és вицькыи. A TESz. a vice szó első írásbeli megjelenését 1631-ből adatolja, és a 'helyettes(itö)' főnévi jelentést ehhez az adathoz köti. A szócikk szerint ez a szó „Magyar fejlemény: jelentéstapadásos elvonással jött létre a viceispán, vicehadnagy, viceszázados típusú összetételek (1. vice- a.) alapján”. A kötőjellel ellátott vice- címszó alatt pedig a vice- elötagú összetett szavakról történik említés: 1470: vicecsászár, 1533: viceplébános, 1535: vicebán, 1540: viceispán stb. Ezek ,jórészt lat. vice- előtagú szószerkezetek részfordításaként, illetőleg ezek analógiájára keletkeztek" (TESz. 3: 1138; az EWUng.-ból a vice címszó hiányzik). E sorokból az következik, hogy a magyar vice szó nem a latin viceimperator, vicecancellarius stb. szavak előtagjának önállósodásából, hanem az összetett magyar szavak előtagjából keletkezett. Nem tudhatjuk, hogy a vice szó, amely ma már elavulófélben van, mióta volt használatban a magyar nyelvben. BARTAL ANTAL a magyarországi latinság szótárában (BARTAL 1901: 695-697) vice- előtaggal számos latin címszót (vicebanus, vicecastellanus, vicedominus, vicegubernator, vicevoyvoda stb.) szerepeltet ugyan, de maga a vice szó nem fordul elő önálló címszóként.

Az alábbiakban azzal a kérdéssel szeretnék foglalkozni - inkább történeti, mint nyelvészeti szempontból -, hogy a fönévi vice szó vajon nem volt-e valaha használatos a magyar nyelvben a 17. századnál már jóval korábban. (Egyúttal megjegyzendő, hogy a német Vize szóra mint fönévre csak a 19. századtól van adatunk; DF. 6: 256, 258).

A kérdéssel kapcsolatban szeretném felhívni a figyelmet HODINKA ANTAL 1916-ban napvilágot látott, Az orosz évkönyvek magyar vonatkozásai címü bilingvis könyvére, amelyben számunkra érdekes szövegrész található, mégpedig a tudós magyar fordításában. A kérdéses passzus a Halics-Volhíniai Évkönyvben (a továbbiakban: HVÉ.) az 1250. évnél olvasható, és Danilo (Dániel) Romanovič halicsi fejedelemnek a tatároknál tett látogatása utáni időkre vonatkozik. „,Az esztendőben a magyar király elküldte hozzá [ti. Dánielhez - S. T.] a vice-jét, mondván: vedd el leányomat Leo fiad részére. Mert félt tőle, mivel ez már a tatároknál is volt és nagy győzelmet aratott Rostislav és magyarjai felett. Dániel tanácskozván fívérével, nem adott hitelt a király szavainak, mivel régen is igérte leányát $\mathrm{s}$ megmásította a szavát. Ez időben Dániel és Vasilko elküldte Ciril metropolitát az orosz metropolia felállításának a kieszközlésére. Midőn a magyar király udvarában időzött, ez szavaival rávette, ajándékokat igérvén neki, hogy: barátságba hozlak a görögökkel, ha Dániel szövetséges viszonyba lép velem. Amaz pedig felelte: esküdjél meg, hogy nem másítod meg szavaidat s akkor én visszatérek s magammal hozom őt. Visszamenvén, mondá Dánielnek: szabad akaratod van, vedd el leányát fiadnak feleségül. Vasilko pedig mondá neki: menj, ő keresztény. Dániel tehát Leo fia és a metropolita kíséretében a királyhoz ment Izvolinba s

Magyar Nyelv 114. 2018: 44-58. DOI: 10.18349/MagyarNyelv.2018.1.44 
elvette leányát fiának feleségül." (HoDINKA 1916: 431, 433; PSRL. 22: 809). Itt Danilo fia, Lev (Leo) és IV. Béla leánya, Konstancia házasságáról van szó, amely egyben a két uralkodó közti béke- és szövetségkötést is jelentette.

HoDINKA - akinek a könyve kevésbé ismert a HVÉ.-vel foglalkozó külföldi szakemberek számára - a magyar fordítást a HVÉ. 1908-as szövegkiadása alapján készítette, amely azóta többször megjelent reprintben, és amelyet gyakorlatilag ma is használnak a szakirodalomban. A magyar vice szó HoDINKA fordításában annak az óorosz (rusz) szónak magyar megfeleltetése, amely a szóban forgó frázisban (присла король Оугорьскыи вицькаго; вицкаго a Chlevnikov-kódexben) а вищькыи genetivusi alakjában, вищькаго-ban bukkan fel. Pontosabban szólva a birtokos személyjelet (-je) hozzáadta a birtokot jelölő szóhoz, ahogy fent látható, tehát HODINKA fordításában a királynak a vicéjéről van szó. A fordításhoz a tudós külön nem füzött magyarázatot, és a vice szónak bizonyára 'helyettes' jelentést tulajdonított régies árnyalattal füszerezve. Ma már azonban nem tudhatjuk, hogy HODINKA a szóban forgó két - óorosz és magyar - szó között látott-e valamiféle etimológiai összefüggést, vagy csupán a szövegkörnyezetből úgy ítélte-e meg, hogy a vice szó jól illeszkedik bele. IZMAIL SREZNEVSKIJ (1893-1912. 1: 266) posztumusz óorosz szótárában, amelynek legutolsó része néhány évvel korábban látott napvilágot HoDINKA munkájánál, a kérdéses szót ugyan felvette címszóként, de ehhez kérdőjelet téve nem adta meg annak jelentését. A magyar tudósnak így nehéz feladattal kellett szembesülnie, noha tagadhatatlan, hogy a magyar szlavisták is hozzájárulhatnak a HVÉ. magyar vonatkozású részeinek megvilágításához. Az utóbbi évtizedekben két nagyszabású óorosz szótár is megjelent, de az egyik csak a kérdéses szó előfordulásának szöveghelyét közli (SRJ. 2: 195), a másik pedig emellett jelzi, hogy a szót melléknévnek tartja, és ennek - kérdőjellel - főnévi szerepet tulajdonít, s szintén nem adja meg a jelentését (SDRJ. 1: 438).

Röviden nézzük meg, hogy a HVÉ. fordítói és kommentátorai hogyan kezelték és értelmezték a kérdéses szót. A HVÉ. 1843-as első kiadásában a kérdéses szót a lengyel witeczny, witeź szóval hozták kapcsolatba (PSRL. $2^{1}$ : 185). Azóta több fordítás és kommentár is megjelent. Az orosz (вестник; LICHAČËV 1997: 257), valamint az ukrán (вісник; MACHNOVEC' 1989: 406) fordításban 'hírnök' jelentésủ szóval ültették át a kérdéses szót. GEORGE A. PERFECKY (1973: 59) angol fordításában a courtier szót használja kérdőjel kíséretében, JITKA KOMENDOVÁ (2010: 84) pedig a cseh fordításból kihagyja a kérdéses szót. MYKOLA KOTLJAR (2002: 262, 2005: 276), aki a HVÉ. Chlevnikov-kódexen alapuló szövegkiadását gondozta, kétségét fejezte ki a fent említett 1843-as értelmezéssel kapcsolatban, és annyit jegyzett meg, hogy talán egy magyar udvari emberrel van dolgunk. Ezekből minden bizonnyal az következik, hogy a kutatók hiába hívták segítségül az óorosz szótárakat, és leginkább a szövegkörnyezetből kényszerültek kitalálni a szó megfelelő jelentését.

2. Вицькыи és Witk/Wytk. A HVÉ. fent idézett híradásával kapcsolatban egy korábbi írásomban (SENGA 1987: 590-594) arra a következtetésre jutottam, hogy a házasságkötés Lev és Konstancia között 1246 szeptemberében történt Zó- 
lyomban. ${ }^{1}$ Ugyanakkor lábjegyzetben hivatkoztam HoDINKA vice-féle fordítására is, ami felkelthette néhány külföldi szakember figyelmét. Újabban ugyanis ezzel kapcsolatban PAVOL MALINIAK tanulmányában közli a HVÉ. kérdéses részének szlovák fordítását, mégpedig a következőképpen: ,a magyar király vický-ja megjött (prišiel vický uhorského krála)". A szlovákul köznévként nem létező vický szóval kapcsolatban megjegyzi, hogy itt a magyar uralkodó helyetteséröl van szó, és a вицькыи szó talán 'a király követe, képviselője' jelentéssel bír (MALINIAK 2008: 129, 13. jegyz.; MALINJAK 2016: 109, 317. jegyz.; vö. MAJOROV 2012: 75, 47. jegyz.). ALEKSANDR MAJOROV pedig újabb tanulmányában futólagosan hozzáfüzi, hogy a kérdéses szó valószínüleg vicecancellarius-ra vagy vicecomes-ra utal (MAJOROV 2016: 48).

DARIUSZ DĄBROWSKI (2012: 269, 699. jegyz.) más lehetőségre mutatott rá, miszerint a вицькыи szó az orosz másoló általi eltorzítása lehet a Witk (Wit'ka genitivusban) névnek, melynek viselője küldetésben járt Ruszban, IV. Béla 1246-ban, mégpedig valamikor október 13-a után kelt oklevele tanúsága szerint (CDES. 2: 157, 227. sz.). Ludány nb. Szoboszló (Sabaslav) fia Wytkröl (Wytk comes, filius Zabazlai de genere Ludan) van szó, akinek a király a nyitrai várbirtok egy részét adta (LUKAČKA 1990: 6, 10; Gy. 4: 368, 420-421). MYROSLAV VOLOŠČUK (2014: 349-357) is hasonlóképpen ugyan, de határozottabban vélekedik, és megpróbálja rekonstruálni Wytk életpályájának halicsi vonatkozásait; még több oklevelet idézvén, például IV. Béla 1253-es oklevelét is, miszerint a király Witknek Szepességben lévő birtokot adományozott Danilo Romanovič fia, Lev kérésére (CDES. 2: 299, 428. sz.; RA. 1: 309, 995. sz.). Itt Witk apjaként Muntahas (patris Witk dicti Muntahas) szerepel (erről a Witkről 1. LABANC 2013: 115-117; vö. KARÁCSONYI 2004: 814-815;

${ }^{1}$ Bár a datálásom egyes külföldi kutatóknál hivatkozásra (KOTLJAR 2002: 262, 2005: 276; NAGIRNYY 2011: 235) vagy elfogadásra (HARDI 2002: 183) talált, az ezzel kapcsolatos érvelésem részletei - amit itt nem ismétlek meg - nehezen jutottak a külföldi szakemberek tudomására addig, míg ezeket PAVOL MALINIAK (2008: 128-133) szlovák nyelvü tanulmányában gyakorlatilag meg nem ismételte azzal a különbséggel, hogy az időpontot közel egy évvel későbbre, 1247 augusztusára helyezte, figyelembe véve az igénybe vett időt Danilo kezdeti tétovázására, az elhúzódó tárgyalásokra, Kirill utazásaira és a szükséges előkészítésekre tekintettel. KOSZTOLNYIK (1996: 203-204) szokatlan eljárása kivételként kezelendő ebben a vonatkozásban. FONT (2005: 249-250, 263, vö. 114, 2016: 102), akinek datálására MALINIAK támaszkodik, a házasság időpontját egyszer 1247 augusztusára teszi - valójában argumentumok nélkül -, máskor pedig 1246-ra helyezi. MALINIAK újabb írásában (MALINJAK 2016: 107; 1. még ROHÁČ 2016: 20) 1247 augusztusára vagy szeptemberére való datálását említi meg az írásomra is hivatkozva, mintha ez lenne véleményem (vö. még MAJOROV 2016: 47). Elutasítva mind ezeket a véleményeket MAJOROV meghökkentő nézetének adott hangot, az esemény időpontját az 1246 júniusában zajlott Lajta menti csatát megelőző időszakra helyezve (MAJOROV 2012: 65-67, 2016: 48), holott más munkáiban (pl. MAJOROV 2011: 422, 671), a tárgyalások kezdetét 1246-ra téve, a házasságkötés idejét 1251-re datálja. BARTNICKI (2005: 188, 37. jegyz.) a házasság idejét vitatott kérdésnek tartva megjegyzi, hogy leggyakrabban 1246-ra helyezik a szakirodalomban. Az utóbbi negyed évszázadban megjelent idevágó monográfiák közül ízelítöül még néhányra utalok, amelyek eltérő megközelítésükkel ugyan, de a házasságkötés idejét mind 1247-re teszik (HOLOVKO 2006: 334; VOJTOVYČ 2012: 34-36, 59; VOLOŠČUK 2014: 354). DARIUSZ DĄBROWSKI (2013: 116117, 38. és 43. jegyz., vö. még 2012: 271-272) pedig - aki elöször vélhetőleg MALINIAK írásán keresztül ismerkedett meg az 1246 szeptemberére való datálásommal - ezt elfogadta, korábbi nézetét (DĄBROWSKI 2007: 53) kissé módosítva s pontosítva megerősítette más forrásadatok bevonásával. 
FONT 1995: 175-177, 184; DĄBROWSKI 2012: 336, 885. jegyz.), így a név azonossága ellenére sem lehet ugyanaz a személy. (Mellesleg megjegyzem, hogy Witkkel kapcsolatban FONT [1995: 176-177.] inkább lengyel eredetre gondol, mintsem halicsira, de szerintem leginkább a Magyar Királyságon belül élő szláv ajkú személy jöhet számításba, vagyis a későbbi szlovák nyelvű lakosság felmenői közül való. A szlovák nyelvü szakirodalomban Wytk/Witk Vitko/Vitko néven jelenik meg.) Az előbbi Wytk Ruszba való követjárása különben is időrendi okoknál fogva aligha vonatkoztatható azon követségre, amelyet IV. Béla 1246-ban menesztett Danilo halicsi fejedelemhez. Felmerül olyan gyanú is, hogy a magyar király ennek a fontos ügynek a lebonyolításáért Halicsba küldött követség élére vajon megfelelőnek és alkalmasnak tartotta-e Wytket és Witket, akik közül egyik sem volt országos méltóságviselő vagy magas rangú egyházi személy. Az a nézet, miszerint az utóbbi Witk a zólyomi házasságkötéssel kapcsolatos ügyekben jeleskedett (VOJTOVYČ 2012: 168), kevésbé valószínủ amiatt, hogy annak megjutalmazására hét év múlva került volna sor. Mindenesetre a Wytk/Witk névforma alakilag olyan messze van a вицькыи (вицькаго) formától, hogy az utóbbi nem lehet az előbbi eltorzult alakja.

3. Nádorispán, kancellár és alkancellár. A magyar királyi oklevelekből, amelyek a Kijevi Ruszban szerzett katonai vagy diplomáciai érdemekről tanúskodnak, egyértelmüen kiviláglik, hogy a magyar királyok többször küldtek követséget Halicsba (FONT 2005: 109-110), bár ezek részletei legtöbbször ismeretlenek. Erre a HVÉ. híradásaiból is hasonlóképpen következtethetünk ugyan, de általában nem ugyanazokról a követjárásokról esik szó, ami azt is jelenti, hogy a két forráscsoport ritkán egészíti ki egymást egy-egy követjárásra vonatkozóan. A magyar királyi oklevelek tanúsága szerint - írja FONT MÁRTA (1995: 170-171) - míg a hadakozásban érdemeket szerzők között elsősorban az előkelő réteg képviselőit látjuk, addig a követjárás szolgálata Halicsban gyakrabban kisebb rangú személyek érdemének mutatkozik. Ez azonban a követjárás céljától is függhet. Mivel 1246-ban a két dinasztia egy-egy tagja közötti házasságkötés a tét, a magyar király a küldöttség élén nem küldhetett akárkit a halicsi fejedelemhez. A kérdéses passzus arra utal, hogy nem üzenetváltásról, szokásos követjárásról lehetett szó, hanem igen fontos diplomáciai feladatról, amiből az következik, hogy a вицькыи szó mögött leginkább egy elökelö, a korabeli elithez tartozó személy lehetett, méghozzá literátus ember, aki mindenekelött a magasabb állású egyháziak köréből került ki (vö. FÜGEDI 1992: 47-48).

Talán nem haszontalan a HVÉ.-ben található, követküldéssel kapcsolatos kifejezések összehasonlítása. A присла (прислати) ige egy accusativusi vagy genitivusi formában lévő köznevet vagy személynevet kíván, így gyakran a посолъ/ посль $\iota$ szó (PSRL. 22: 782, 808 stb.), ritkán pedig személynév szerepel mellette (1253: Тевтивиль присла Ревбоу река; PSRL. 22: 818). Nem megy ritkaságszámba az, hogy ezek említése hiányzik. Például az 1252. évnél a Присла король Оугорьскы к Данилоу (PSRL. 22: 813) passzus található, amelyből nem tudjuk meg, hogy a király kit (vagy mit) küldött Danilóhoz. Így a fordítók gyakran - zárójelben vagy anélkül - kiegészítően betesznek egy 'követ' jelentésű szót (PERFECKY 1973: 61; MACHNOVEC'1989: 408; KOMENDOVÁ 2010: 87; vö. HodINKA 1916: 435; LICHAČËV 1997: 261). Így különleges esetnek tünne, ha a szóban forgó pasz- 
szus nem tartozna egyik példához sem, és a kérdéses szó nem lenne valamiféle köznév vagy személynév.

А вицькыл е́s a magyar vice szó félig-meddig hasonló hangzása ahhoz a találgatáshoz vezet, hogy vajon a kettő kapcsolatban áll-e etimológiailag egymással. На а вицькыл szó jelentése 'helyettes' lenne, nem lenne nehéz arra gondolni, hogy nádorispánnal (nádorral) van dolgunk, tekintettel arra, hogy a nádori tisztséget viselőnek a királyt helyettesítő szerepe volt politikai ügyekben is ezekben az időkben. A HVÉ.-ben azonban arról történik említés, hogy a magyar király a вицькblu-t és nem a „вицькыı-jét” vagy - HoDINKA fenti fordítása szerint - a ,vice-jét” küldte el Danilóhoz. Elgondolkodtató az a jelenség, hogy vice- előtaggal több tisztségnév ismert a 13. századi Magyar Királyságból. Bár a magyar nyelvü gyakorlati, jogügyi írásbeliség még a 14. században is gyerekcipőben járt (ISTVÁNYI 1934: 12-13), abból, hogy a latin comes palatinus (vagy palatinus comes) titulus magyar megfelelője valószínűleg már az Árpád-korban létezett, mégpedig a nádorispán formájában (SzŐCS 2014: 13), arra is joggal következtethetnénk, hogy a nádorhelyettesre a vicenádorispán- vagy vicenádor-féle magyar nyelvü kifejezés is létezett. A nádorhelyettes latin megnevezése, amelynek első hiteles említése 1220-ból való, kezdetben alkalomszerủ és nem egységes. A 13. század közepétől fogva nagyjából kétféle nádorhelyettesi funkciót kell megkülönböztetni. Az egyik nádorhelyettesi funkciót a vicepalatinus (alnádor) látta el, akinek feladata „nem csak a nádor személyének helyettesítése volt, hanem az, hogy Pesten, később Budán székelve ellássa a pesti ispáni teendőket, illetve a regióban bíráskodjon”. A másik funkciót pedig a viceiudex (albíró) hivatala jelentette, aki „közvetlenül a nádor személyes munkatársa volt, többnyire a környezetében tartózkodott, és a nádor személyét helyettesítette". (SzŐCS 2014: 56, 249. jegyz., 203).

Diplomáciai feladatok ellátására a cancellarius lehetett hivatottabb és alkalmasabb a 13. század első évtizedeiben. Nem kivételes az a jelenség, hogy a királyi kancellárság irányítója jár külföldi küldöttségekbe. Jó példa erre Tamás kancellár esete, aki 1209-ben első alkancellárként bukkan fel, és akit II. András 1214-ben kelt oklevele szerint elküldtek Bulgáriába, hogy elhozza Boril bolgár cár leányát, II. András fiának, Bélának a jegyesét. Az oklevél „Tamás fehérvári prépost, a királyi udvar kancellárja kezéből” kelt (ÉRSZEGI 1975: 96-97). A vicekancellári vagy alkancellári állás pedig II. András idején született, aki a notariusok és kancellárok közé 1209-ben beékelte ezt a tisztséget, és amelynek majd IV. Béla idején nagyobb szerepe lett az oklevelek kiállítása terén, amivel együtt bekövetkezett a kancellár visszavonulása a kancellária közvetlen vezetésétől (FEJÉRPATAKY 1885: 36, 38; SZENTPÉTERY 1930: 85). IV. Béla alatt alkancellárok nem egyszer szerepelnek politikai ügyekben, fontos országos ügyek tárgyalásánál „, király megbízottaiként, annak jeléül, hogy állásuk sok elfoglaltsággal járó bizalmi állás" (SZENTPÉTERY 1930: 87). Tehát egyáltalán nem furcsa jelenség az, hogy a 13. század derekán nem a kancellár, hanem az alkancellár teljesíti a külföldi követjárások fontos feladatát a király megbízásából. Így a вицьккыи is - Tamás kancellár feladatához hasonlóan - a HVÉ. híradásából ítélve azért utazhatott Halicsba, hogy kieszközölje a magyar király leányának a halicsi fejedelem fiával való összeházasítását. A két körülmény egybekapcsolása arra enged következtetni, hogy egy 
alkancellár vezette azt a küldöttséget Halicsba, amelynek fő feladata a IV. Béla leánya és Danilo fia közötti házasság megvalósítása volt. Feltételezhető tehát, hogy а вицькыи, akit 1246-ban IV. Béla fontos diplomáciai feladattal Halicsba küldött, a vicecancellarius-szal azonosítható. Ennek alapján feltételezhetjük azt, hogy a vicecancellarius és a вищькыи között valamilyen összefüggés van.

4. Achilles alkancellár. Ismeretes, hogy az alkancellári tisztséget 1243 és 1250 között Hontpázmány nb. Pázmány fia, Achilles töltötte be, aki egyidejűleg fehérvári prépost is volt, majd 1251-ben pécsi püspök lett (ZSOLDOS 2011: 94, 110, 281), így következésképpen nagy a valószínüsége annak, hogy а вицькыи nem más, mint Achilles alkancellár. Pályafutása hasonlóságot mutat Tamás kancelláréhoz, II. András idejéből, hiszen az utóbbi is kancellársága idején (1209-1217) veszprémi, szebeni és fehérvári prépost volt, majd egri püspök (1217-1224), azután pedig esztergomi érsek (1224) lett (ZsOLDOS 2011: 107, 353). Achilles életpályája jól illeszkedik abba a képbe, hogy a magyar király alkancellárokat küld külföldre, hogy diplomáciai szolgálatot teljesítsenek. KOSZTA LÁSZLÓ tanulmányában, aki a magyar történetírásban elöször írt részletesen Achilles pécsi püspök életpályájáról, természetesen nem szól Achilles halicsi követjárásáról. Megjegyzi, hogy IV. Béla 1251-ben a kilenc éve hivatalban lévő Achillest - aki 1243 ősze elején foglalta el a fehérvári prépostságot és vette át elödjétől az alkancellári tisztséget - püspöki ranggal jutalmazta. És a király ,elismeróen emlékszik meg a királyi szolgálatban eltöltött idejéröl” 1251. július 23-án kelt oklevelében, amelyböl - teszi hozzá KOSZTA - érződik, hogy a király személyesen ismerte és nagyra becsülte Achillest (KOSZTA 2007: 173, 179; SZENTPÉTERY 1930: 87).

Bár a magyar királyi oklevelek csak ritkán örökítik meg a követküldésekről szóló információkat időponthoz kötve, egy oklevélben a HVE. fentebb idézett szövegrészében szereplő magyar követségre vonatkoztatható sorok megtalálhatók. IV. Béla 1244. április 22-én kelt okleveléből, amelyet egyes kutatók hamisnak vélnek (RA. 1: 228, 763. sz.), arról értesülünk, hogy Obichk fia Miklós (Nicolaus, filius Obichk de Zyud) azután járt Danilo halicsi fejedelemnél, miután az hazájába visszatért a tatárok fejénél tett látogatásáról. Még arról is szó esik benne, hogy Miklós a halicsi fejedelemtől ígéretet nyert, hogy a tatárok állapotáról hivatalos oklevélben be fog számolni (CDES. 2: 101-102, 150. sz.; Zyud nem Szúddal [szlk. Súdovce; vö. CDES. 2: 101], hanem Szüggyel [Gy. 4: 303-304; 3: 213-214] azonosítandó. Miklósról és rokonairól 1. KARÁCSONYI 2004: 652-654; FONT 1995: 174-175, 184). Ezen oklevél - amelynek az idevágó tartalma bizonyára hitelt érdemel, keltezése viszont nem² „Achilles magiszter, fehérvári prépost és udvarunk alkancellárja” kezéből kelt.

${ }^{2}$ PAULER (2: 520-521, 147. jegyz.; 523, 164. jegyz.) az oklevelet hitelesnek vélte, csak keltét 1246-ra korrigálta. Arra való tekintettel, hogy az oklevél szerint a király uralkodásának 20. évében, vagyis 1254-ben kelt, LEDERER (1961: 192, 22. jegyz.; vö. FONT 2005: 113-114) az oklevél keletkezését 1254-re tette, ami kevésbé valószínü, hiszen ekkor Achilles nem volt már alkancellár. Vélhetőleg valamikor 1247 és 1250 között kelt az oklevél, amelyben Miklósnak a magyarországi tatárjárás idején és ezután szerzett érdemeiről esik szó. Újabban MAJOROV (2013: 56-58, 70-71), valóban 1244-ben kelt hiteles oklevélnek tartva (1. még VOLOŠČUK 2008: 32-34) úgy véli, hogy Kijev közelében nem később, mint 1239 novemberében találkozott a tatárok vezérével Danilo halicsi fejedelem, akit nem sokkal ezután keresett fel Miklós. 
Amikor Achilles alkancellár volt (1243-1250), Benedek kalocsai érsek töltötte be a kancellári tisztséget (ZSOLDOS 2011: 84, 108, 289). Achilles alkancellársága idejének első felében kelt oklevelei többször a kancellár kezéből kerültek ki ugyan, de a második felében kizárólag Achilles nevét írják a formulába. Benedek kancellár -írja tovább KOSZTA LÁSZLÓ - időként ténylegesen bekapcsolódott a kancelláriai munkába és annak irányításába. (KoszTA 2007: 174, 83-84. jegyz.; vö. FEJÉRPATAKY 1885: 40.) Nem maradt ránk 1246-ból olyan oklevél, amely jelzi, hogy kinek (kancellárnak vagy alkancellárnak) kezéből kelt, 1247-ből pedig egy nevezetes királyi oklevélben mind a két személy felbukkan. Az oklevél - amely a király adományozásáról szól a johannita rendnek - „Benedek kalocsai érsek és udvarunk kancellárja" kezéből kelt ugyan, de az ezt megelőző sorokból kitünik, hogy „,szeretett és hüséges magiszterünk, Achilles fehérvári prépost és udvarunk alkancellárja" iktatta be Rembaldust, a johanniták preceptorát (rendfönökét) az adományozott javak birtokába (DRH. 24, 10. sz.; RA. 1: 257, 853. sz.). Ebben nincs semmi különös, hiszen ,a magasabb státusú egyéneket magasabb egyházi funkciót betöltők vagy országos méltóságviselők vezették be birtokaiba" (FÜGEDI 1992: 46). Mégis gyanítható, hogy 1246 tájától - amely átmeneti időszak lehet az alkancellári tisztség feladatkörére nézve - gyakorlatilag Achilles irányította az oklevéladást, és Benedek kancellár, aki magas egyházi méltóságából adódó elfoglaltságai miatt vélhetően az oklevéladás ügyeivel és a kancellária irányításával alig foglalkozhatott, csak névlegesen szerepelt a datum per manus keltezési formulában.

Összevetve a HVÉ. fentebb említett tudósítását, valamint az Obichk fia Miklós érdemeiről szóló okleveles híradást úgy tünik, hogy a IV. Béla és Danilo közötti ellenséges viszonyok - amelyeket az 1245. augusztusi Jarosław (ukr. Ярослав) alatti csata jellemez - enyhültek 1246 közepén, és ekkor a tatárok elleni közös fellépések is napirendre kerülhettek köztük. Egy korábbi írásomban nem tartottam kizártnak, hogy а вицькыли azonos ezen Miklóssal. Az eddig előadottak fényében azonban valószínübbnek tartom most már, hogy Obichk fia Miklós 1246-ban, miután a halicsi fejedelem hazatért a tatároktól, Achilles alkancellárral (а вицькыли-vel) együtt utazott Halicsba Danilóhoz. És ha a halicsi fejedelem 1246 májusa körül tért haza a tatároktól, IV. Béla szintén ekkortájban menesztette ezen követségét Halicsba (SENGA 1987: 590), élén Achilles vicekancellárral. A HVÉ. és a királyi oklevél híradásai jól kiegészítik egymást, noha nincs kizárva, hogy IV. Béla két külön küldöttséget indított Halicsba 1246 derekán egymás után, az egyik az alkancelláré, a másik pedig Miklósé volt. Az Achilles alkancellár vezette követség célja bizonyára kettős volt: egyrészt a dinasztikus rokoni kapcsolatok kiépítése, másrészt pedig friss és megbízható információk szerzése a tatárok viselt dolgairól, így ezáltal tulajdonképpen a királyság védelmi képességének vagy ütőképességének megerősítése.

5. Kirill kancellár és a HVÉ. Amennyiben a вицьккыи szó a magyar vice hatására keletkezett, megválaszolandó, hogy ez a későbbi kutatóknak fejtörést okozó rejtélyes szó hogyan került be a HVÉ. szókészletébe. A fentebb hivatkozott óorosz szótárakban sem a вuщe, sem pedig a вuщe- előtaggal ellátott szavak nem szerepelnek címszóként, és az utóbbiak (вице-адмирал, вище-канилер stb.) is csak 
I. Péter orosz cár idejétől lettek használatosak holland vagy német közvetítéssel (ESRJ. 1: 324). Az óukrán szótár szerint 1404-ből ismert a вицашпань névalak (SSUM.1: 177), a szlovák viceišpán szóra pedig 1483-ból van adatunk (HSSJ. 6: 356), de ezek nyilvánvalóan a magyar viceispán szóval hozhatók kapcsolatba. Magától értetődő, hogy nem voltak használatosak a latin eredetü вuue- előtaggal rendelkező tisztségnevek a Halicsi Fejedelemségben, ahol a cancellarius tisztségnévnek a печатникъ felelt meg.

Nem fér sok kétség ahhoz, hogy Kirill metropolita azonos azzal a Kirillel, aki a HVÉ.-ben az 1241. évnél Danilo halicsi fejedelem печатникъ-jaként bukkan fel (PSRL. 22: 791-792; 1. JUSUPOVIĆ 2013: 313-316). A pečatnik (pecsétőr) - mely tisztség ismeretlen más Rusz-beli fejedelemségeknél - fejedelmi pecsétet őriz, ezt használja a fejedelmi dokumentumokban, valamint az iratot összeállítja vagy az összeállítását irányítja, ahogy a nyugat-európai kancellárok csinálják (KRYP'JAKEVYČ 1999: 163; 1. még HALBACH 1985: 241-249; KOTLJAR 2008: 278; JUSUPOVIĆ 2013: 37-38). A Magyar Királyságban a kancellár őrizte az aranypecsét nyomóját, Achilles alkancellár pedig a király kettős pecsétjét gondozta, amelynek előlapját mindig magánál tartotta (KOSZTA 2007: 175; SZENTPÉTERY 1930: 87). Kirill metropolita vélhetően Halicsban - Danilo udvarában - már találkozott IV. Béla követével, Achilles alkancellárral, majd a magyar király udvarában és 1246 szeptemberében pedig Zólyomban is. Kirill, aki Danilo udvarában kancellárként müködött, a magyar királyi kancellárság müködése iránt bizonyára érdeklődést mutatott, és feltünt neki, hogy annak irányítója gyakorlatilag nem kancellár, hanem vicekancellár volt. Ilyen körülmények között okunk van feltételezni, hogy Kirillnek - és a halicsi fejedelem kísérőinek egyaránt - alkalma volt tudomást szerezni arról, hogy a király udvarában és környezetében ezekben az időkben a vice szó éppen Achilles alkancellár jelölésére szolgált az élőbeszédben.

Úgy vélem, hogy Kirill metropolitának köze van a вицькыи szó létrejöttéhez, ami a HVÉ. keletkezése és szerzősége kérdésének bonyolult és vitatott problematikájával állhat összefüggésben. Ezzel kapcsolatban ALEKSANDR UŽANKOV, aki a korábbi kutatások eredményeit áttekinti, kritikai megjegyzéseket füzve hozzájuk, úgy foglal állást, hogy a HVÉ. halicsi részét, Danilo Romanovič krónikáját (Летописец Даниила Галицкого) két szakaszra lehet osztani: az első szerkesztés az 1205-1247 eleje (az Ipat'jev-kódexben az 1201-1250. évek) közötti eseményeket fogalja magában, a második pedig az 1247 második fele és 1260 (az Ipat'jevkódexben az 1251-1261. évek) közötti eseményeket. Felhívja a figyelmet arra, hogy az első redakcióban - amely most bennünket közelebbről érdekel - az 1247 után lezajlott eseményekre nem található utalás (UžANKOV 2009: 316, 324-325). Tudott dolog, hogy a HVÉ.-ben egy-egy adott időben lezajlott esemény leírásába csak később, illetve a jövőben tudható információ is beékelődik. Ezt UžANKOV konkrét példákkal támasztja alá, amelyek közül több magyar vonatkozású is van. Annak oka, hogy UŽANKOV miért szerepelteti az első redakció végének időpontjául 1247 elejét és a második szerkesztés kezdetének időpontjául 1247 második felét, a következőkben rejlik. A Danilo Romanovič fia, Lev és IV. Béla leánya, Konstancia közti házasságkötés időpontját ugyanis - amely szerintem 1246 szeptemberére tehető - UŽANKOV 1247 elejére helyezi a szakirodalomra való hivatko- 
zás nélkül (UŽANKOV 2009: 316; 1. még JUSUPOVIĆ 2013: 28-29). Mivel ez az esemény a HVÉ.-ben az 1250. évnél időrendileg az utolsó, arra gondol, hogy az Évkönyv szerzője saját munkáját 1247-ben fejezte be. A következő évnél, 1251nél is említés történik egy 1247-es eseményről, nevezetesen Konrad mazóviai fejedelem haláláról, amely 1247 . augusztus 31 -én következett be (JASIŃSKI 2001: 32-33). UŽANKOV szerint az 1251. évi híradás elején négy év (1247-1251) eseményei vannak összetömörítve, amiben retrospektív nézőpont érződik a leírt eseményekben, és az 1251. évnél leírtaktól kezdve kezdődik a második redakció, amely 1262 után készült (UŽANKOV 2009: 316-318). Ha helytálló az említett datálásom, UŽANKOV következtetése akképpen módosítandó, hogy a HVÉ. halicsi része első felének redakciója nem 1247-ben, hanem 1246-ban fejeződött be, mégpedig nem sokkal 1246 szeptembere után, és a második rész redakciója az 1247. évtől kezdődő eseményeket foglalta magában. Leszámítva az utólagos betoldásokat, elmondható tehát, hogy a HVÉ.-ben az 1250. évig (valójában 1246-ig) terjedő rész egyértelműen elkülöníthető az 1251. évtől (valójában 1247-től) kezdődő résztől, és a HVÉ. halicsi részén belül a határkő 1246 és 1247 közé helyezhető. Ami az első redakció szerzőjét illeti, UžANKOV $(2009$ : 354, 356) Kirill metropolitát nevezi meg, aki a korábbi kutatásokban is felmerült mint szerzőjelölt. Kirill Nikaiába való elindulásának időpontját illetően szintén bizonytalanság figyelhető meg a szakirodalomban, ami zavarossá teszi a kérdést (vö. az újabb szakirodalomból pl. HARDI 2002: 183, 43. jegyz.; BARTNICKI 2005: 126; HOLOVKO 2006: 334; NAGIRNYJ 2011: 235; MAJOROV 2011: 702; VOJTOVYČ 2012: 35-36). Le kell szögeznem, hogy Kirill kevéssel 1246 szeptembere után indult Nikaiába (1. még DĄBROWSKI 2013: 117), így bizonyos, hogy akkortájt tette le a tollat. Így érthetővé válik, hogy ettől kezdve közel egy évig (1246. szeptember - 1247. augusztus) gyakorlatilag nem történt bejegyzés a HVÉ.-be, míg a második redakció el nem kezdi az elbeszélést Konrad 1247 augusztusában bekövetkezett halála megemlítésével. (Ezekkel a körülményekkel nehezen összehangolható az a nézet [vö. 1. jegyz.], miszerint a IV. Béla leánya és Danilo fia közti házasságkötés - amelynél Kirill is jelen volt - 1247 augusztusában vagy szeptemberében zajlott volna le.) Az, hogy Kirill volt a HVÉ. 1250-ig (valójában 1246-ig) terjedő részének összeállítója, azt jelenti, hogy a HVÉ. szóban forgó részében közölt események szemlélője és egyben egyik fő szereplője maga Kirill volt, így nem meglepő, hogy a vonatkozó leírások meglehetősen élénknek tủnnek.

6. Vicekancellár, vice és вицькыи. A vicecancellarius tisztségnév 1209 óta adatoltan létezett (CDES. 1: 120-123, 152-154. sz.; RA. 77-79, 241-243. sz.), és a 13. század közepén már megszokott elnevezés. Ahogy a nádorispán tisztségnév, úgy vélhetőleg a magyar nyelvü vicekancellár titulus is - mely forma igen közel áll a latin alakhoz - használatban volt a 13. század derekán az alkancellár-ét megelőzően. Ekkor már a vice szó magyar főnévként kezdett gyökeret verni az élőbeszédben, esetleg anélkül, hogy ezzel egy konkrét méltóságnévre utalna. A TESz. (3: 1138) szerint a vice szónak - amelynek időrendileg az első jelentése 'helyettes(itö)' - a második jelentése pedig 'segéd-házfelügyelö', amelyre a 19. század végétől van adatunk. Ebben az esetben biztosra vehető, hogy a német 
Vizehausmeister mintájára keletkezett viceházmester szóból rövidült le a vice szó. Talán nem lenne meglepő, hogy IV. Béla udvarában és környezetében hasonló dolog történhetett, vagyis a vicekancellárt egyszerúen vicének is hívhatták. Bár az írásbeliséget a latin határozta meg, a szóbeliség pedig mindig is többnyelvü volt, mégis a magyar nyelvet beszélők voltak többségben (SOLYMOSI 2011: 483-484, 497). Az a körülmény is figyelembe veendő, hogy ezekben az időkben az ország lakossága szóbeli kultúrában élt, és a magyar királyok is, akik feltételezhetően nem tudtak latinul, főleg a szóbeliség eszköztárára támaszkodva kormányoztak (FÜGEDI 1992: 48). Kirill metropolitának, aki IV. Béla udvarában tartózkodott 1246-ban, alkalma lehetett hallani, hogy a vice szót önállóan, főnévként használják az élőbeszédben.

Az eddigi fejtegetéseim csak akkor nyerhetnének nagyobb valószínüséget, ha a вицькыи szó keletkezésének körülményeit nyelvészetileg is megfelelően tudnám alátámasztani, ami nyelvtudományi ismereteim hiányából adódóan merész vállalkozás lenne. Amennyiben nem feltételezem, hogy a вицьккыи szó egy bizonyos név eltorzult alakja, vagy valami kiesett a szó előtt vagy utána stb., azaz nem számolok a szövegromlással, arra kell választ keresni, hogy a kérdéses szó milyen módon van összefüggésben a magyar vice fönévvel. Magam csupán igen egyszerü magyarázatot tudok adni a vice és a вицькыи közti alaki viszonyokról. A szláv nyelvekben a -ce (-ice) végződésű helynevek melléknevesítésénél megfigyelhető azon jelenség, hogy az - e magánhangzó kiesik, és ehhez hozzáadódik a - $k$ - melléknévképző, ami nem megy ritkaságszámba. Például a lengyel városnév, Katowice szláv melléknévi formái: le. katowicki, ukr. катовіиький, or. катовицкий, szlk. katovický, valamint a szlovák Košice (> szlk. košický stb.) városnév melléknevei is hasonlóképpen viselkednek. A вицькыи névalakot is így képezhették a magyar főnévi vice szóból. Ha figyelmen kívül hagynánk a magyar szót, feltehetnénk azt a kérdést, hogy vajon а вицькыи milyen szónak lehet a melléknevesítése az óoroszban. Erre a * вuúe szó lehet a válasz, noha ez nem adatolt a korabeli forrásokból. Mindenesetre akkor magyarázatra szorul, hogy а вицькыи miért van melléknévi formában, bár melléknevek gyakran fönevesülnek.

Ebben a vonatkozásban érdekes lehet, hogy a HVÉ.-ben többször találkozhatunk egy melléknévi formából fönevesült tisztségnévvel, a дворьскыи-vel (udvarmesterrel), amely nyilván a $\partial в о р ъ$ fönévhez - $c \kappa-$ melléknévképző csatolásával jött létre. Az óorosz nyelv szótára szerint jelentése 'hivatali személy fejedelem, bojár stb. udvaránál' (SDRJ. 2: 449), ami bizonyára az 'udvarhoz tartozó' jelentésből fakad, ahogy a melléknévi palatinus eredetileg a 'palotához tartozó' jelentéssel bír. A palatinus comes (vagy comes palatinus) összetételben ugyanis - amely a bevett latin megnevezés volt a 12. században a nádorispánra - a palatinus a comes jelzője volt, és a század végétől kezdett lekopni a comes tag, és a 13. század elejétől önálló főnévként a palatinus (nádor) lett lassan használatos (SzÖCs 2014: 1416). Ahogy a palatinus önálló főnév lett a palatinus comes kifejezésböl, elvileg a дворьскыи is eredetileg egy fönév jelzőjeként elképzelhető lenne. Olyan nézet is kapott hangot a szakirodalomban, miszerint a Magyar Királyságban használt tisztviselői terminológia lemásolásával és lefordításával van dolgunk (HALBACH 
1985: 232-235; JUSUPOVIĆ 2013: 38-43; vö. KOTLJAR 2008: 263-271). ${ }^{3}$ Ami most közelebbről érdekel, az az, hogy a дворьскыи szóhoz mint fönévhez a szóképzés szempontjából hasonlóságot mutat a вицькыи, hiszen az utóbbi is a magyar vice fónévhez - az - e kiesésével - melléknévképző - - - (-kblu) hozzáadásával jött létre (vö.palatium > palatinus; дворъ > дворьскыи; вице (vıсе) > вищькыи).

7. Záró gondolat. A вищъкыı szó - ha az ehhez hasonló hangzású szláv személynévhez nincs köze - tiszavirág életünek mondható, amely csak a HVÉ.-ben bukkan fel egyetlen egyszer, és keletkezése oly módon magyarázható meg, hogy ezt a szót a magyar vice főnév hatására hívták életre melléknévképzővel ellátva (vic $+-k$-) fönévként. Kirill metropolitának, aki maga is kancellár volt, bizonyára feltünt, hogy nem a kancellár, hanem az alkancellár irányítja a magyar királyi kancelláriát. Az elmondottak fényében valószínüsíthetö, hogy а вищькыи ritka és eddig megfejthetetlen szó tulajdonképpen a vicecancellarius lerövidült formája, amolyan informális, inkább a beszélt nyelvre jellemző megnevezése lehetett a vicekancellárnak, amelyet Kirill keltett életre a IV. Béla udvarában s környezetében használatos magyar vice szó alapján.

Összefoglalva utólagosan elmondható, hogy HoDINKA ANTAL száz évvel ezelőtti vice-féle magyar fordítása szellemes és találó, de szerintem annyiban módosítandó, hogy a király nem a „vicé-jét”, azaz helyettesét, hanem - az eredeti alak meghagyásával - a vic 'kyi-t küldte el Danilo halicsi fejedelemhez. Ehhez magyarázatul hozzáfüzhető, hogy ez a magyar vice szó alapján életre kelt szó. És arra a kérdésre, hogy ki is volt a vic 'kyi, az a válasz adható, hogy valószínüleg Achilles alkancellárról van szó. ${ }^{4}$

Kulcsszók: vice, вицькьıи, vicecancellarius, Achilles alkancellár, Kirill metropolita, a magyar-halicsi kapcsolatok 1246-ban, a Halics-Volhíniai Évkönyv.

\section{Hivatkozott irodalom}

BARTAL, ANTONIUS 1901. Glossarium mediae et infimae latinitatis regni Hungariae. A magyarországi latinság szótára. Teubner-Franklin, Lipsiae-Budapest. (Reprint: ÁKV, Budapest, 1983).

${ }^{3}$ A дворьскыи és a palatinus tisztségviselő - föleg katonai vonatkozású - feladatkörének egybevetése érdekes ugyan, de annyi megjegyzendő, hogy a HVÉ.-ben Pot, aki 1211-ben a magyar hadsereget vezényelte Halicsba, nem дворьскыи-ként, hanem великыи дворьскыи-ként szerepel (PSRL. 2²: 724), és HodinKA (1916: 286, 317) 'legfőbb udvarnok'-nak fordította, tudva azt is, hogy Pot (Pat) nádorról (Zsoldos 2011: 17, 169,343) van szó.

${ }^{4}$ Nem sokkal a kézirat lezárása (2017. szeptembere) után megjelent a Chlevnikov-kódexen alapuló HVÉ. szövegkiadása, valamint lengyel fordítása: Kronika halicko-wołyńska (Kronika Romanowiczów). Wydali, wstępem i przypisami opatrzyli DARIUSz DĄBROWSKI i ADRIAN JUSUPOVIĆ. (Pomniki Dziejowe Polski, Seria II. Tom 16.) Polska Akademia Umiejętności, Kraków. 2017; Kronika halicko-wołyńska. Kronika Romanowiczów. Tłumaczenie, wstęp i komentarze DARIUSz DĄBROWSKI i ADRIAN JusuPOVIĆ. Avalon, Kraków-Warszawa. 2017. Az utóbbi könyv (179. oldal, 911. jegyzet), amely az eddigi szakirodalomban a legbővebb kommentárt tartalmazza, a kérdéses passzust a következőképpen fordítja: ,przyslał król węgierski Witka jego" (< Вицька его < вицкаго). 
BARTNICKI, MARIUSz 2005. Polityka zagraniczna księcia Daniela Halickiego w latach 1217-1264. Wydawnictwo UMCS, Lublin.

CDES. = Codex diplomaticus et epistolaris Slovaciae. 1-2. Ed. RICHARD MARSINA. SAV.Obzor, Bratislavae, 1971-1987.

DĄBROWSKI, DARIUSZ 2007. Stosunki polityczne między królem Węgier Belą IV, niektórymi książętami polskimi i Romanowiczami w latach 1242-1250 (ze szczególnym uwzględnieniem kwestii matrymonialnych). In: ZBIGNIEW ZYGLEWSKI red., Polska $w$ kręgu polityki, kultury i gospodarki europejskiej. Księga pamiątkowa z okazji 70-lecia urodzin prof. Maksymiliana Grzegorza. Wydawnictwo Uniwersytetu Kazimierza Wielkiego, Bydgoszcz. 45-63.

DĄBROWSKI, DARIUSZ 2012. Daniel Romanowicz. Król Rusi. (ok. 1201-1264). Biografia polityczna. Avalon, Kraków.

DĄBROWSKI, DARIUSZ 2013. Slovak and Southern Slavic Threads in the Genealogy of the Piast and Rurikid Dynasties in the Thirteenth Century. In: MARTIN HOMZA - JÁN LUKAČKA - NEVEN BUdAK eds., Slovakia and Croatia. Historical Parallels and Connections (until 1780). PostScriptum, Bratislava-Zagreb. 110-119.

DF. = Deutsches Fremdwörterbuch . Begonnen von HANS SCHULZ, fortgeführt von OTTO BASLER weitergeführt im Institut für deutsche Sprache. 1-7. Walter de Gruyter, Berlin - New York, 1974-1988.

DRH. = Documenta Romaniae historica: D. Relaţii între Ţările Romane Volumul I (12221456). Volum întocmit de ŞTEFAN PASCU [et al.]. Editura Academiei Republicii Socialiste România, Bucureşti, 1977.

ÉRSZEGI, GÉZA 1975. Eine neue Quelle zur Geschichte der bulgarisch-ungarischen Beziehungen während der Herrschaft Borils. Bulgarian Historical Review 3/2: 91-97.

ESRJ. = МАКС ФАСМЕР, Этимологический словарь русского языка 1-4. Перевод с немецкого и дополнения О. Н. ТРУБАЧЕВА; под редакцией и с предисловием Б. А. ЛАРИНА. Изд. 2-е, стереотипное. Прогресс, Москва, 1986-1987.

EWUng. = Etymologisches Wörterbuch des Ungarischen 1-2. Hrsg. BENKÖ LORÁND. Akadémiai Kiadó, Budapest, 1993-1995. + Register. Akadémiai Kiadó, Budapest, 1997.

FEJÉRPATAKY LÁSZLÓ 1885. A királyi kanczellária az Árpádok korában. M. T. Akadémia, Budapest. (Reprint: Históriaantik Könyvesház, Budapest, 2010).

FONT MÁRTA 1995. Felvidéki kisnemesek királyi szolgálatban. Adalékok 13-14. századi társadalomtörténetünkhöz. In: KoszTA LÁSZLÓ szerk., Kelet és Nyugat között. Történeti tanulmányok Kristó Gyula tiszteletére. Szegedi Középkorász Mühely, Szeged. 169-185.

FONT MÁRTA 2005. Árpád-házi királyok és Rurikida fejedelmek. Szegedi Középkortörténeti Könyvtár 21. Szegedi Középkorász Mühely, Szeged.

FONT, MARTA 2016. Даниил Романович «Галицкий» и Венгерское Королевство. In: JITKA KOMENDOVÁ SZERK., Письменность Галицко-Вольнского княжества: историко-филологические исследования. Univerzita Palackého v Olomouci, Olomouc. 91-105.

FÜGEDI ERIK 1992. IV. Béla adományai és a szóbeliség. Levéltári Közlemények 63: 39-52.

Gy. = GYÖRFFY GYÖRGY, Az Árpád-kori Magyarország történeti földrajza 1-4. Akadémiai Kiadó, Budapest, 1963-1998. 
HalBaCH, UwE 1985. Der russische Fürstenhof vor dem 16. Jahrhundert. Eine vergleichende Untersuchung zur politischen Lexikologie und Verfassungsgeschichte der alten Rus. Quellen und Studien zur Geschichte des östlichen Europa 23. Steiner, Stuttgart.

HARDI, ĐURA 2002. Наследници Кијева између краљевске круне и татарског јарма: студија о државно-правном положају Галичке и Галичко-Волинске кнежевине до 1264. године. Филозофски факултет, Катедра за историју, Нови Сад.

Holovko, Oleksandr BORYSOvyČ 2006. Корона Данила Галииького: Волинь $i$ Галичина в державно-політичному розвитку Центрально-Східної Європи раннього та класичного середньовіччя. Стилос, Київ.

HSSJ. = Historický slovník slovenského jazyka 1-7. Ved. red. MILAN MAJTÁN. Veda, Bratislava, 1991-2008.

ISTVÁNYI GÉZA 1934. A magyarnyelvü irásbeliség kialakulása. A Pázmány Péter Tudományegyetem Történelmi szemináriumának kiadványai 1 . Oklevél és címertani tanszék, Budapest.

JASIŃSKI, KAZIMIERZ 2001. Rodowód Piastów małopolskich i kujawskich. Biblioteka Genealogiczna 3. Wydawnictwo Historyczne, Wrocław-Poznań.

JUSUPOVIĆ, ADRIAN 2013. Elity ziemi halickiej $i$ wotyńskiej w czasach Romanowiczów (ok. 1205-1269). Avalon, Kraków.

KARÁCSONYI JÁNOS 2004. A magyar nemzetségek a XIV. század közepéig. 2. utánny. Nap Kiadó, Budapest.

KomendOVÁ, JiTKA 2010. Haličsko-volyňský letopis. Argo, Praha.

KOSZTA LÁSZLÓ 2007. Hont-Pázmány nembeli Achilles pécsi püspök (1205/1210-1252.). In: Fedeles TAMÁs - HorvÁth ISTVÁN - Kiss Gergely szerk., A pécsi egyházmegye vonzásában: Ünnepi tanulmányok Tímár György tiszteletére. METEM - Historia Ecclesiastica Hungarica Alapítvány, Budapest. 163-190.

KosZTOLNYIK, ZOLTÁN J. 1996. Hungary in the thirteenth century. East European Monographs 439. Boulder, New York.

Kotluar, MyKola FEDOROVyČ 2002. Галицьько-Волинський літопис. Дослідження. Текст. Коментар. За ред. М.Ф. КотЛЯРА. Наукова Думка, Київ.

Kotluar, MyKola FedorovyČ 2008. Княжий двір Галича. In: М. Ф. КОтЛЯР - В. М. РичкА, Княжий двір Південної Pусі X-XIII cm. Нац. акад. наук України, Ін-т історії України. Наукова думка, Київ.

Kotluar, NikOlaj FËDOROVIČ 2005. Галицєко-Вольнская летопись. Текст. Комментарий. Исследование. Под ред. Н. Ф. КОТЛяРА. Алетейя, СПб.

KRYP'JAKEVYČ, IVAN 1999. Галицько-Волинське князівство. Інститут українознавства ім. Крип'якевича НАН України, Львів.

LABANC, PETER 2013. Vývoj šl’achty na Spiši do začiatku 14. storočia. Filozofická fakulta Trnavskej univerzity v Trnave - Spolok Slovákov v Pol'sku, Trnava-Kraków.

LEDERER, EMMA 1961. Венгерско-русские отношения и татаро-монгольское нашествие. In: А. А. ЗИМИН - В. Т. ПАШУТО ред., Международные связи России до XVII в.: сборник статей. Изд-во Академии Наук СССР, Москва. 181-202.

LICHAČËV, DMITRIJ SERGEEVIČ 1997. Галицко-Волынская летопись. Подготовка текста, перевод и комментарии О. П. Лихачевой. In: Д. С. ЛихАчЕВ и др. ред., Библиотека литературы Древней Руси. Том 5. ХІІІ век. Наука, СПб. 184-357, 482-515.

LUKAČKA, JÁN 1990. Majetky a postavenie Ludanickovcov na Slovensku do začiatku 14. storočia. Historický časopis 38: 3-14. 
MAJOROV, ALEKSANDR VjaČESLAVOVIČ 2011. Русь, Византия и Западная Европа. Из истории внешнеполитических и культурных связей конца XII - начала ХІІІ вв. Studiorum Slavicorum orbis, вып. 1. Дмитрий Буланин, СПб.

MAJOROV, ALEKSANDR VJAČESLAVOVIČ 2012. «Король Руси» в битве на Лейте. Русин 3: 54-77.

MAJOROV, AleKSANDR VJAČESLAVOVIČ 2013. Даниил Галицкий и «принц Тартар» накануне нашествия Батыя на Южную Русь. Русин 1: 53-77.

MAJOROV, ALEKSANDR VJAČESLAVOVIČ 2016. "Cum quodam rege Ruscie singulariter in prelio dimicans...»: был ли Даниил Галицкий участником битвы на Лейте? Древняя Русь. Вопросы медиевистики 4: 35-51.

MACHNOVEC', LEONID 1989. Літопис руський за іпатським списком переклав ЛЕОНІД МАХНОВЕЦь. Дніпро, Київ.

MALINIAK, PAVOL 2008. K sobášnej politike Bela IV. Dynastická svadba vo Zvolene a jej reflexie v historiografii. Historicky casopis 56: 125-136.

MALINJAK, PAVOL 2016. Свадьба в королевской крепости Зволен: к вопросу о региональном взаимодействии в венгерско-галицких отношениях. In: JITKA KOMENDOVÁ szerk., Письменность Галицко-Вольнского княжества: историко-филологические исследования. Univerzita Palackého v Olomouci, Olomouc. 107-116.

NagirnyJ, Witaliy 2011. Polityka zagraniczna księstw ziem halickiej $i$ wotyńskiej $w$ latach 1198 (1199)-1264. Prace Komisji Wschodnioeuropejskiej 12. Polska Akademia Umiejętności, Kraków.

PAUler GyUla 1899. A magyar nemzet története az Árpádházi királyok alatt 1-2. Atheneum, Budapest (Reprint: ÁKV, Budapest, 1984, ÉRSZEGI GÉZA által összeállított Név- és tárgymutatóval).

Perfecky, GeOrge A. 1973. The Galician-Volynian Chronicle. An Annotated Translation by George A. Perfecky. W. Fink, München.

PSRL. $2^{1}$. = Ипатьевская летопись. (Полное собрание русских летописей, изданное по высочайшему повелению Археографическою комиссиею т. 2). Типография Эдуарда Праца, СПб., 1843.

PSRL. $2^{2}$. = Ипатьевская летопись. (Полное собрание русских летописей т. 2). Языки русской культуры, Москва, 1998.

RA. = Az Árpád-házi királyok okleveleinek kritikai jegyzéke 1-2. Szerk. SzENTPÉTERY IMRE - BORSA IVÁN. MTA, Akadémiai Kiadó, Budapest, 1923-1987.

ROHÁČ, PETER 2016. Boj o babenberské dedičstvo a I. česko-uhorská vojna 1252-1254. Vojenská história 20/1: 18-42.

SDRJ. = Словарь древнерусского языка (XI-XIV вв.) 1-11 (свене - стягъ). Русский язык-Азбуковник, Москва, 1988-2016.

SENGA TORU 1987. IV. Béla külpolitikája és IV. Ince pápához intézett „tatár-levele”. Századok 121: 584-612.

SOLYMOSI LÁSZLÓ 2011. Anyanyelv és jogi írásbeliség a középkori Magyarországon. Történelmi Szemle 53: 479-501.

SRJ. = Словарь русского языка XI-XVII вв 1-30 (томъ-уберечися). Наука-НесторИстория, Москва-СПб., 1975-2015.

SREZNEVSKIJ, IZMAIL IVANOVIČ 1893-1912. Словарь древнерусского языка - Материаль для словаря древнерусского языка 1-3. СПб. (Книга, Москва, 1989. Репринтное изд.) 
SSUM. = Словник староукраӥнської мови, XIV-XV cm. 1-2. Інститут суспільних наук (Академія наук Українскої РСР). Наукова думка. Київ, 1977-1978.

SzENTPÉTERY IMRE 1930. Magyar oklevéltan. Magyar Történelmi Társulat, Budapest. (Reprint: Hatágú Síp Alapítvány, Budapest,1995.)

TESz. = A magyar nyelv történeti-etimológiai szótára 1-3. Főszerk. BENKÖ LORÁND. Akadémiai Kiadó, Budapest, 1967-1976. + Mutató. Akadémiai Kiadó, Budapest, 1984.

UŽANKOV, ALEKSANDR NiKOLAEVIČ 2009. Проблемь историографии и текстологии древнерусских памятников XI-XIII веков. Рукописные памятники Древней Руси, Москва.

VoJTOVyČ, LeOnTIJ 2012. Князь Лев Данилович. Институт украиноведения им. И. Крипякевича НАН Украины, Львов.

VOLOŠČUK, MYROSLAV 2008. Проблема кількості візитів Данила Романовича in Tartaria: джерелознавчий аналіз угорського диплому від 22 квітня 1244 p. In: Дрогичинъ 1253. Матеріали Міжнародної наукової конферениії з нагоди 755-ї річнииі коронації Данила Романовича. ЛІК, Івано-Франківськ. 18-36.

VOLOŠČUK, MYROSLAV 2014. «Русь» в Угорському королівстві (ХI - друга половина XIV cm.): суспільно-політична роль, майнові стосунки, міграції. Лілея-НВ, ІваноФранківськ.

ZsOLDOS ATTILA 2011. Magyarország világi archontológiája 1000-1301. MTA Történettudományi Intézete, Budapest.

\section{Vice Chancellor Achilles in Halych in 1246: Data on the history of Hungarian vice 'deputy'}

In its 1250 entry, the Galician-Volhynian Chronicle reports that the King of Hungary sent а вищькыли to Danilo, Prince of Halych (Galicia), with the intention of marrying his daughter off to Danilo's son. Antal Hodinka, who translated the part of text concerned in his bilingual book a century ago, interpreted вицькыл аs the "vice" of the Hungarian king. The Hungarian word vice 'deputy' is getting obsolete today. Were it the king's deputy that was meant, it would refer to the Palatine, an official whose roles included standing in for the king in political matters in those days; but as far as diplomacy was concerned, chancellors and vice-chancellors were more entitled to serve those tasks. The present author thinks that some months prior to the marriage taking place in Zólyom (Slovakian: Zvolen) in September 1246, Béla IV may have sent Vice Chancellor Achilles to the Prince of Halych. Achilles also met with Metropolitan Cyril, both in Halych and later in Hungary. The Metropolitan, who was a chancellor of Danilo, and who compiled part of the Chronicle up to 1250 (actually, 1246), noticed that the royal chancery of Hungary was practically directed by the vice chancellor, rather than by the chancellor himself. It appears to be highly probable that it may have been Cyril who revived the word вицькыли on the basis of the noun vice being in use in Béla IV's court referring to Vice Chancellor Achilles in everyday parlance.

Keywords: vice, вицькыли, vicecancellarius, Vice Chancellor Achilles, Metropolitan Cyril, Hungarian-Galician relations in 1246, The Galician-Volhynian Chronicle.

SENGATORU

Budakeszi-Chita (Japán) 